ISSN: 2581-8341

Volume 04 Issue 12 December 2021

DOI: 10.47191/ijcsrr/V4-i12-22, Impact Factor: 5.825

\title{
Influence of Working Capital Management and Policy to Profitability of Retail Trading Sector in Indonesia
}

\author{
Eric Tjandra \\ School of Business and Management Institut Teknologi Bandung, Indonesia
}

\begin{abstract}
Working Capital (WC) is an important aspect of any firms because of its correlation to risk (liquidity) and return (profitability). This research examines the influence of WC Management and Policy (WCMP) to profitability of 21 listed retail trading sector firms in Indonesia from 2011-2020 using panel data regression. In this research, WC Management (WCM) is measured by Cash Conversion Cycle (CCC) and its components which are Days Sales Outstanding (DSO), Days Inventory Outstanding, and Days Payable Outstanding (DPO); WC Policy is measured current assets divided by total assets or referred to as WC Investment Policy (WCIP) and current liabilities divided by total assets or referred to as WC Financing Policy (WCFP); and profitability is measured by Earnings Before Interest, Tax, Depreciation, and Amortization Margin (EBITDAM). The results show that firms can increase EBITDAM by shortening CCC, primarily through shortening DIO and lengthening DPO. Further, firms may improve EBITDAM by adopting a conservative WC Policy instead of an aggressive one, which means having higher current assets and lower current liabilities with respect to total assets.
\end{abstract}

KEYWORDS: Cash Conversion Cycle; Profitability; Working Capital Management; Working Capital Policy; Working Capital

\section{INTRODUCTION}

Corporate finance involves financial decision making which traditionally encompasses investment, capital structure, and dividend to maximize firm value which is often associated with shareholders value. Financial decisions are also segregated into long-term and short-term. The short-term aspect which involves Working Capital (WC) Management and Policy (WCMP) is essential as firms need to survive in the short-term to thrive in the long-term (Pouraghajan \& Emamgholipourarchi, 2012). Efficient WCMP is an integral part of financial management to increase shareholders' value (Enqvist, Graham, \& Nikkinen, 2014).

Main subjects of WCMP are cash, Accounts Receivable (AR), Accounts Payable (AP), and inventory. WCMP should be balanced and optimal to achieve maximum profit and cash flow (Goel, 2013). WCMP is relevant in every sector, firm size, country, and type of economy (Bhatia \& Srivastava, 2016). However, WCMP could be more impactful in certain sectors, such as the retail trading sector. Retail trading sector is a WC-intensive sector where AR, AP, and inventory make up a significant portion of the statement of financial position.

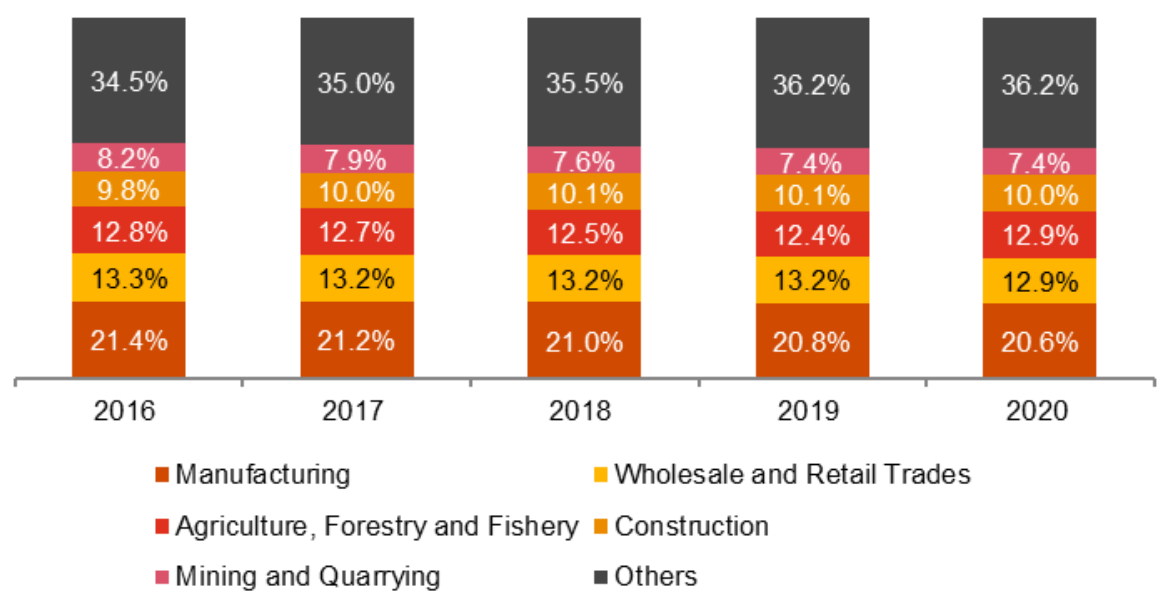

Figure 1: Indonesia GDP Composition (Constant Price 2010 basis) 


\section{International Journal of Current Science Research and Review}

ISSN: 2581-8341

Volume 04 Issue 12 December 2021

DOI: 10.47191/ijesrr/V4-i12-22, Impact Factor: 5.825

IJCSRR@ 2021

WwW.ijcsrr.org

As shown on Figure 1, wholesale and retail trade is a strategic sector in the growth of Indonesia's economy and is the second largest contributor to Indonesia's Gross Domestic Product (GDP), only behind manufacturing. Wholesale and retail trade consistently contributed c. $13 \%$ to Indonesia's GDP (constant price 2010 basis) in the last five years. This is also true despite the COVID-19 pandemic outbreak in early 2020. From 2016 to 2019, the said sector grew at 4\%-5\%, however, GDP of wholesale and retail trade sector contracted by $3.7 \%$ in 2020 due to COVID-19 leading to mobility restrictions.

In this research, WC Management (WCM) is measured by Cash Conversion Cycle (CCC) and its components which are Days Sales Outstanding (DSO), Days Inventory Outstanding, and Days Payable Outstanding (DPO); WC Policy is measured current assets divided by total assets or referred to as WC Investment Policy (WCIP) and current liabilities divided by total assets or referred to as WC Financing Policy (WCFP); and profitability is measured by Earnings Before Interest, Tax, Depreciation, and Amortization Margin (EBITDAM).

This research will also contribute to the existing body of knowledge because it has a novel feature where the profitability measure is EBITDAM. Most research on the influence of WCMP to profitability in the past used gross operating profit, return on assets, return on equity, and/or return on invested capital to measure profitability. EBITDA is selected in this research because it is a commonly used metric in valuation. The advantage of EBITDA is that it isolates the impact of corporate finance decisions which are capital expenditure, debt funding and tax impact. This allows better comparability between research subjects and allows assessment that is focused on operational efficiency of firms.

This research will examine the influence of WCMP to profitability of retail trading sector in Indonesia for several reasons. First, retail trading sector is a WC-intensive sector. Second, retail trading sector plays an important role in the economy of Indonesia contributing c. $13 \%$ of GDP. Third, there are mixed results on the influence of WCMP to profitability in previous researches as shown by Table I. Last, to the writer's knowledge, there are no (or very limited) prior research examining specifically retail trading subsector in Indonesia as the research subject.

Table I: Previous Research on WCMP Influence to Profitability

\begin{tabular}{|c|c|c|c|c|c|c|}
\hline No & Citation & Horizon & Industry & Source & WCM & WC Policy \\
\hline 1 & $\begin{array}{l}\quad \text { (Pouraghajan \& } \\
\text { Emamgholipourarchi, } \\
\text { 2012) }\end{array}$ & $2006-2010$ & Mixed & $\begin{array}{l}\text { Tehran Stock } \\
\text { Exchange (Iran) }\end{array}$ & CCC: $(-)$ & $\begin{array}{l}\text { Investment: }(+) \\
\text { Financing: }(-)\end{array}$ \\
\hline 2 & $\begin{array}{l}\text { (Bhatia \& Srivastava, } \\
\text { 2016) }\end{array}$ & $2000-2014$ & Mixed & $\begin{array}{l}\text { Bombay Stock } \\
\text { Exchange (India) }\end{array}$ & $\begin{array}{l}\text { CCC, DIO, DSO: (-) } \\
\text { DPO: }(+)\end{array}$ & Not assessed \\
\hline 3 & $\begin{array}{l}\text { (Basyith, Djazuli, \& } \\
\text { Fauzi, 2021) }\end{array}$ & $2000-2019$ & Mixed & $\begin{array}{l}\text { Indonesia Stock } \\
\text { Exchange }\end{array}$ & $\begin{array}{l}\text { CCC, DIO, DSO: } \\
(-) \\
\text { DPO: }(+)\end{array}$ & $\begin{array}{l}\text { Investment: }(+) \\
\text { Financing: }(-)\end{array}$ \\
\hline 4 & (Napompech, 2012) & $2007-2009$ & Mixed & Thai listed firms & $\begin{array}{l}\text { CCC, DIO, DSO, } \\
\text { DPO: (-) }\end{array}$ & sessed \\
\hline 5 & (Pais \& Gama, 2015) & $2002-2009$ & Mixed & Portuguese SMEs & $\begin{array}{l}\text { CCC, DIO, DSO, } \\
\text { DPO: (-) }\end{array}$ & $\begin{array}{l}\text { Investment, } \\
\text { Financing: (+) }\end{array}$ \\
\hline 6 & $\begin{array}{l}\text { (Vural, Sökmen, \& } \\
\text { Çetenak, 2012) }\end{array}$ & $2002-2009$ & Manufacturing & $\begin{array}{l}\text { Istanbul Stock } \\
\text { Exchange } \\
\text { (Turkey) }\end{array}$ & $\begin{array}{l}\text { CCC, DIO, DSO: } \\
(-) \\
\text { DPO: }(+)\end{array}$ & Not assessed \\
\hline 7 & $\begin{array}{l}\text { (Enqvist, Graham, \& } \\
\text { Nikkinen, 2014) }\end{array}$ & 1990-2008 & Mixed & $\begin{array}{l}\text { Nasdaq Helsinki } \\
\text { Stock Exchange } \\
\text { (Finland) }\end{array}$ & $\begin{array}{l}\text { CCC, DIO, DSO, } \\
\text { DPO: (-) }\end{array}$ & Not assessed \\
\hline 8 & $\begin{array}{ll}\text { (Louw, Hall, } \quad \& \\
\text { Brümmer, }\end{array}$ & 2004-2012 & Retail & $\begin{array}{l}\text { Johannesburg } \\
\text { Securities } \\
\text { Exchange (South } \\
\text { Africa) }\end{array}$ & $\begin{array}{l}\text { CCC, DIO, DSO, } \\
\text { DPO: }(+)\end{array}$ & Not assessed \\
\hline
\end{tabular}




\section{International Journal of Current Science Research and Review}

ISSN: 2581-8341

Volume 04 Issue 12 December 2021

DOI: 10.47191/ijcsrr/V4-i12-22, Impact Factor: 5.825

IJCSRR@ 2021

WwW.ijesrr.org

WC is the bloed of any firm and is often associated as the short-term financial profile and operating liquidity of the business. Firms require WC to conduct its operations smoothly, consequently, insufficient level of WC may lead to daily operational issues including insolvency as the firm fails to service its liabilities as they fall (Basyith, Djazuli, \& Fauzi, 2021). In technical terms, WC reflects the operating accounts of the businesses and is defined as current assets less current liabilities.

There is a trade-off between risk and profitability in WCMP (Gitman \& Zutter, 2015). Higher level of WC or current assets decreases the risk of insolvency, provides opportunity to make early payments to get discounts, and increases revenue opportunity by holding more inventory. However, excessive investment in WC decreases profitability as the excess funds could be utilized elsewhere with higher returns. On the other hand, a lower level of WC allows capital to be allocated to higher yield assets, but then the firm has higher risk of insolvency and inventory stock-out costs. The objective of WCMP is to ensure the firm's smooth daily operations while investing its resources in the most productive manner. This suggests that aggressive WC Policy, i.e. lower WCIP and higher WCFP which means lower WC is favorable to profitability. Consequently, it suggests that lower CCC, i.e. lower DSO, lower DIO, and higher DPO which translates to lower WC is favorable to profitability. Then,

Previous researches on WCM presented on Table I are broadly in line with the theory of (Gitman \& Zutter, 2015) where CCC, DSO, and DIO influences profitability negatively and DPO influences profitability positively. However, there are some contradictions such as findings by (Napompech, 2012); (Pais \& Gama, 2015); and (Enqvist, Graham, \& Nikkinen, 2014) where DPO influences profitability negatively. Further, (Louw, Hall, \& Brümmer, 2016) found that CCC, DSO, and DIO influences profitability positively on South African retail firms.

On WC Policy, only the finding on WCFP by (Pais \& Gama, 2015) is consistent with (Gitman \& Zutter, 2015). Findings on WCFP by (Pouraghajan \& Emamgholipourarchi, 2012) and (Basyith, Djazuli, \& Fauzi, 2021) and finding on WCIP by (Pais \& Gama, 2015) are in contradiction with (Gitman \& Zutter, 2015).

Considering the literature and previous researches, the hypothesis developed in this research is as follows.

1. CCC has negative influence to profitability

2. DSO has negative influence to profitability

3. DIO has negative influence to profitability

4. DPO has positive influence to profitability

5. WCIP has negative influence to profitability

6. WCFP has positive influence to profitability

\section{METHODOLOGY}

The research population is firms listed in the Indonesian Stock Exchange (IDX) under the retail trading subsector from 2011-2020. The data used in this research is secondary data in the form of financial statements. As of 30 September 2021 , there are 28 firms in the population. The research samples are firms with financial information required for the research that is available in Morningstar (https://www.morningstar.com/) and Finbox (https://finbox.com/). The number of firms with the required data is 21 firms as listed below. Not all sample firms have complete financial data (2011-2020), hence the data is an unbalanced panel data.

The analysis method to test the formulated hypothesis as explained previously is multiple linear regression. The regression tool used in this research will be Stata/SE 17.0. Multiple linear regression tests the influence of independent variables on a dependent variable. The variables are explained on Table II. In this research, the hypotheses will be tested with two regression models below.

(1) $E B I T D A M=a+C C C+W C I P+W C F P+S i z e+S G R O W+\varepsilon$

(2) $E B I T D A M=a+D S O+D I O+D P O+W C I P+W C F P+S i z e+S G R O W+\varepsilon$

Table II: List of Variables

\begin{tabular}{lll}
\hline Variables & Abbreviation & Formula \\
\hline Dependent Variable & & \\
\hline EBITDA Margin & EBITDAM & EBITDA / Sales \\
\hline Independent Variables & & \\
\hline \multicolumn{1}{c}{ Cash Conversion Cycle } & CCC & DSO + DIO - DPO
\end{tabular}




\section{International Journal of Current Science Research and Review}

ISSN: 2581-8341

Volume 04 Issue 12 December 2021

DOI: 10.47191/ijcsrr/V4-i12-22, Impact Factor: 5.825

IJCSRR@ 2021

www.ijesrr.org

\begin{tabular}{lll}
\hline Days Sales Outstanding & DSO & Average Accounts Receivable / Sales x 365 \\
\hline Days Inventory Outstanding & DIO & Average Accounts Payable / Cost of Sales x 365 \\
Days Payable Outstanding & DPO & Average Inventory / Cost of Sales x 365 \\
\hline Working Capital Investment Policy WCIP & Current Assets / Total Assets \\
\hline $\begin{array}{l}\text { Working Capital Financing Policy } \\
\text { WCFP }\end{array}$ & Current Liabilities / Total Assets \\
\hline Control Variables & & \\
\hline Size & SIZE & Natural logarithm of Sales \\
\hline Sales Growth & SGROW & (Sales Current Period / Sales Prior Period) - 1 \\
\hline
\end{tabular}

\section{RESULTS AND DISCUSSION}

Table III: Cluster-Robust Standard Errors Panel Regression Results

\begin{tabular}{|c|c|c|c|c|}
\hline & \multicolumn{2}{|c|}{ Regression Model 1} & \multicolumn{2}{|c|}{ Regression Model 2} \\
\hline Variable & Coefficient & $\mathbf{P}>|\mathbf{t}|$ & Coefficient & $\mathbf{P}>|\mathbf{t}|$ \\
\hline $\mathrm{CCC}$ & -0.00100 & $0.000 *$ & & \\
\hline $\mathrm{DSO}$ & & & -0.00271 & 0.142 \\
\hline $\mathrm{DIO}$ & & & -0.00107 & $0.000 *$ \\
\hline DPO & & & 0.00042 & $0.001 *$ \\
\hline WCIP & 0.74043 & $0.044 *$ & 0.76534 & $0.038 *$ \\
\hline WCFP & -0.02366 & $0.038 *$ & -0.01994 & $0.004 *$ \\
\hline SIZE & 0.01238 & 0.185 & -0.00202 & 0.853 \\
\hline SGROW & -0.00027 & 0.422 & -0.00060 & 0.361 \\
\hline Constant & -0.59294 & 0.069 & -0.32606 & 0.203 \\
\hline Adj R-squared & $59.8 \%$ & & $62.6 \%$ & \\
\hline Prob $>F$ & & 0.000 & & 0.000 \\
\hline
\end{tabular}

Notes: * represents significance at a minimum of 5\% level; there is heteroscedascity and autocorrelation detected, hence the clusterrobust standard errors regression is used

\section{Results}

Based on Table III, both regression models suggest similar results and statistical significance. On the independent variables, only DSO on Regression Model 2 has no statistical significance. Other independent variables which are CCC, DIO, DPO, WCIP and WCFP showed statistical significance at $1 \%$ to $5 \%$ level.

In the research subjects, inventory and AP is a core item in the statement of financial position. During 2018-2020, inventory represented an average of $27 \%-32 \%$ of total assets while AP represented an average of 32\%-39\% of total assets. Meanwhile, AR contributed much less at an average of $11 \%-14 \%$ of total assets. The lower contribution by AR is possibly the reason why it has no significant influence to EBITDAM, as opposed to AP and inventory. Most of the research subjects are Direct-to-Consumer (DTC) business selling daily necessities and fashion, hence having low AR as the customers pay in cash (zero DSO) or by card (minimum DSO).

The adjusted coefficient of determination (Adj R-squared) of both regression models are approximately $60 \%$. This means that the independent variables in this research explain approximately $60 \%$ of the variation in the dependent variable. The remaining approximately $40 \%$ of the variation in the dependent variable is explained by other variables which are not included in the regression model.

The coefficient of CCC, DSO and DIO is negative while DPO is positive which confirms the hypotheses. This means that the shorter the CCC (CCC = DSO + DIO - DPO) the higher the EBITDAM of a firm will be. The coefficient sign of DSO, DIO and DPO in Regression Model 2 show consistent results with the CCC equation. The negative influence of CCC to EBITDAM is consistent with 


\section{International Journal of Current Science Research and Review}

ISSN: 2581-8341

Volume 04 Issue 12 December 2021

DOI: 10.47191/ijcsrr/V4-i12-22, Impact Factor: 5.825

IJCSRR@ 2021

www.ijcsrr.org

most of the results of previous research on Table I and (Gitman \& Zutter, 2015), although previous research use different measures of profitability.

As for WC Policy, the regressions results in both models show that WCIP has positive influence to profitability meaning that a more conservative WCIP (more current assets in balance sheet) is favorable to profitability. In line with that, WCFP has negative influence to EBITDAM meaning that a more conservative WCFP (less current liabilities in balance sheet) is favorable to EBITDAM. This finding rejects the hypotheses developed previously as it is contradictory to (Gitman \& Zutter, 2015). However, this finding is broadly consistent with the results of previous research on Table I.

\section{Discussion}

The results suggest that lower CCC results in better EBITDAM. Commercially, firms that are able to convert from inventory to receivables, then from receivables to cash faster and firms able to delay the settlement of payables longer ultimately leading to less WC requirement and better cash profile will result in better EBITDAM. Previous research explains that lower CCC yields higher profitability because the firm incurs less borrowing or financing cost, however in this research the profitability proxy is EBITDAM (does not incorporate interest expense). Therefore, the explanation could be that a firm with less restricted capital could invest its capital elsewhere to finance its growth and profitability such as strategic acquisitions, expansionary capital expenditure, and strategic/operational transformation. The impact of these investments could be both aspects, increasing revenue to drive economies of scale and managing operational expense for better efficiency.

In terms of WC Policy, firms are better off with a conservative approach or higher WC. This could be due to the difficulty if not impossible, to determine the minimum level of WC (aggressive WC Policy) to maximize profitability. Possibly, firms that try to do so are under pressure resulting in non-optimal decisions. For example, firms are forced to put up significant discounts to turnover inventory, provide significant discounts to collect receivables, charged with penalty to extend dues to suppliers, etc. Instead, it is better for firms to be conservative in its WC Policy which is expected to make the firm more resilient and allow it to operate in a more sustainable manner. The safety buffer may also allow firms to survive in unpredictable situations such as in this COVID-19 era and/or allocate capital to higher return investments once the opportunity comes up.

\section{CONCLUSION}

The objective of this study is to understand the influence of WCMP to profitability of retail trading sector firms listed in Indonesia from 2011-2020. The regression results show that there is significant influence of CCC, DIO, DPO, WCIP, and WCFP on EBITDA. The result where CCC (calculated by DSO + DIO - DPO) has negative influence on EBITDA is consistent with most of the previous research and theory. However, the results where WCIP and WCFP have positive and negative influence on EBITDA, respectively, are consistent with most of the previous research but contradictory with the theory.

The results from this study confirm that retail firm managers could put emphasis on WCMP as it could impact profitability, which is one of the most if not the most important goal of any firms. Managers should make initiatives to decrease CCC by focusing in decreasing DIO and increasing DPO which will ultimately free some capital. Then, the capital could be utilized for higher return investments, such as on fixed assets. Other than that, it is suggested that firms employ a conservative WC Policy to operate sustainably as opposed to aiming for profit maximization through an aggressive WC Policy as it comes with various risks.

It is recommended that future research study the impact of WCMP to bankruptcy or liquidity, for example using Altman Z-Score or Springate S-Score. Research could also be extended to other WC-intensive sectors such as manufacturing. Manufacturing is also a key sector in Indonesia.

\section{REFERENCES}

1. Basyith, A., Djazuli, A., \& Fauzi, F. (2021). Does Working Capital Management Affect Profitability? Empirical Evidence from Indonesia Listed Firms. Asian Economic and Financial Review, 236-251.

2. Bhatia, S., \& Srivastava, A. (2016). Working Capital Management and Firm Performance in Emerging Economies: Evidence from India. Management and Labour Studies, 1-17.

3. Enqvist, J., Graham, M., \& Nikkinen, J. (2014). The impact of working capital management on firm profitability in different business cycles: Evidence from Finland. Research in International Business and Finance, 36-49.

4. Gitman, L. J., \& Zutter, C. J. (2015). Principles of Managerial Finance. Pearson. 


\section{International Journal of Current Science Research and Review}

ISSN: 2581-8341

Volume 04 Issue 12 December 2021

DOI: 10.47191/ijesrr/V4-i12-22, Impact Factor: 5.825

IJCSRR@ 2021

www.ijesrr.org

5. Goel, S. (2013). Working Capital Management Efficiency and Firm Profitability: A Study of Indian Retail Industry. South Asian Journal of Management, 104-121.

6. Louw, E., Hall, J., \& Brümmer, L. (2016). Working Capital Management of South African Retail Firms. Journal of Economic and Financial Sciences, 545-560.

7. Napompech, K. (2012). Effects of Working Capital Management on the Profitability of Thai Listed Firms. International Journal of Trade, Economics and Finance, 227-232.

8. Pais, M. A., \& Gama, P. M. (2015). Working Capital Management and SMEs Profitability: Portuguese Evidence. International Journal of Managerial Finance, 341-358.

9. Pouraghajan, A., \& Emamgholipourarchi, M. (2012). Impact of Working Capital Management on Profitability and Market Evaluation: Evidence from Tehran Stock Exchange. International Journal of Business and Social Science, 311 -318.

10. Vural, G., Sökmen, A. G., \& Çetenak, E. H. (2012). Affects of Working Capital Management on Firm's Performance: Evidence from Turkey. International Journal of Economics and Financial Issues, 488-495.

Cite this Article: Eric Tjandra (2021). Influence of Working Capital Management and Policy to Profitability of Retail Trading Sector in Indonesia. International Journal of Current Science Research and Review, 4(12), 1776-1781 